\title{
Aplikasi Risk Based Capital dan Rasio Keuangan dalam Penilaian Tingkat Kesehatan PT Asuransi Jiwasraya (Studi Kasus pada Periode Sebelum Kebangkrutan)
}

\author{
Dharamega Carissa Henrita, Apriani Dorkas Rambu Atahau \\ Universitas Kristen Satya Wacana
}

Email: 212017171@student.uksw.edu

Naskah diterima 24 Maret 2020, Revisi 30 Maret 2020, Terbit 19 April 2020

\begin{abstract}
Abstrak
DOI: doi.org/10.21107/pamator.v13i1.6975

Penelitian ini memiliki tujuan, yaitu untuk mengukur kesehatan keuangan perusahaan asuransi PT Asuransi Jiwasraya melalui Risk Based Capital dan Rasio keuangan ditengah maraknya kasus yang dihadapi. Tiga rasio keuangan yang digunakan berdasarkan Pernyataan Standar Akuntansi Keuangan (PSAK) Nomor 28 tentang Akuntansi Asuransi Kerugian. Metode Risk Based Capital yang digunakan berdasarkan peraturan yang ditetapkan pemerintah. Jenis penelitian ini termasuk dalam penelitian deskriptif dengan menggunakan pendekatan kuantitatif. Sumber data yang digunakan dalam penelitian ini yaitu data sekunder didapat dari laporan keuangan perusahaan asuransi PT Asuransi Jiwasraya. Teknik pengumpulan data yang dilakukan adalah dengan mengambil dari laporan keuangan PT Asuransi Jiwasraya periode tahun 2008 - 2017 atau masa - masa sebelum terjadinya kabangkrutan. Hasil keseluruhan dari penelitian ini menunjukan bahwa kesehatan PT Asuransi Jiwasraya pada tahun 2008 hingga 2017 sudah cukup baik hasil Risk Based Capitalnya cenderung memenuhi standar, beberapa rasio keuangan perusahaan mengalami beberapa penyimpangan dimana presentasenya mendekati batas normal dan tidak stabil pada waktu - waktu tertentu.
\end{abstract}

Kata Kunci: tingkat kesehatan keuangan perusahaan asuransi, analisis rasio keuangan, risk based capital

\begin{abstract}
This research has an objective, which is to measure the financial health of insurance company PT Asuransi Jiwasraya through Risk Based Capital and financial ratios amid the many cases being faced. Three financial ratios are used based on Statement of Financial Accounting Standards (PSAK) No. 28 concerning Accounting for Insurance for Losses. The Risk Based Capital method is used based on regulations established by the government. This type of research is included in descriptive research using a quantitative approach. The data source used in this study is secondary data obtained from the financial statements of insurance companies PT Asuransi Jiwasraya. The technique of data collection is done by taking from the financial statements of PT Asuransi Jiwasraya for the period 2008 - 2017 or the periods before bankruptcy. The overall results of this study indicate that the health of PT Asuransi Jiwasraya in 2008 to 2017 is good enough. The Risk Based Capital results tend to meet standards, some of the company's financial ratios experience some irregularities where the presentation approaches normal and unstable limits at certain times.
\end{abstract}

Keywords : financial soundness of insurance companies, financial ratio analysis, risk based capital

\section{PENDAHULUAN}

Pertumbuhan perusahaan di Indonesia mengalami peningkatan dari tahun ke tahun. Tidak hanya perusahaan pada bidang perdagangan saja yang bersaing dalam dunia perbisnisan, namun perusahaan pada bidang jasa pun mulai menunjukan eksistensinya. Salah satu perusahaan jasa yang ikut berkembang adalah perusahaan asuransi. Seiring dengan berkembangnya perusahaan-perusahaan
Indonesia membuat meningkat pula persaingan diantara perusahaan tersebut dan juga risiko - risiko lebih besar akan bermunculan. Perusahaan akan memikirkan strategi alternatif agar perusahaan lebih untung.

Menurut Maharani (2019) berhasilnya sebuah perusahaan dapat diprediksi dengan melihat kinerja keuangan perusahaan tersebut. Kinerja keuangan sebuah perusahaan dalam dunia bisnis seringkali 
dikaitkan dengan kesehatan sebuah perusahaan. Seirama dengan manusia yang harus selalu menjaga kesehatannya, perusahaan asuransi pun juga harus selalu dinilai kesehatannya agar tetap prima dalam melayani para pengguna jasanya. Perusahaan asuransi yang tidak sehat, bukan hanya membahayakan dirinya sendiri, akan tetapi juga pihak lain yang mempercayakan pada perusahaan asuransi tersebut.

Sehat dalam hal ini diartikan bahwa perusahaan tersebut dapat bertahan dalam kondisi ekonomi apapun. Hal ini dapat dilihat dari kemampuan perusahaan tersebut dalam memenuhi kewajiban - kewajibannya. Suatu perusahaan umumnya didirikan untuk memperoleh kemampuan laba yang maksimal dengan harapan dapat mempertahankan kelangsungan hidup perusahaan dan mencapai tujuan bersama. Upaya perusahaan untuk menjaga kelangsungan usaha dan meminimalisir risiko dapat dimulai dengan menggunakan kinerja dengan baik.

Efektif atau tidak kinerja keuangan pada sebuah perusahaaan, dapat diukur dari rasio keuangan perusahaan (Maharani, 2019). Menurut Janudin (2018) Laporan keuangan merupakan salah satu alat yang berarti bagi pihak intern maupun pihak ekstern perusahaan untuk memperoleh informasi yang berhubungan dengan posisi keuangan dan hasil yang telah dicapai oleh sebuah perusahaan. Untuk menilai kesehatan sebuah perusahaan asuransi pemerintah telah mengeluarkan Peraturan Menteri Kcuangan Nomor 53/ PMK.OIO/ 2012 tentang kesehatan keuangan perusahaan asuransi dan perusahaan reasuransi, perusahaan diwajibkan melampaui tingkat solvabilitas terrendah $100 \%$ dan pencapaian di setiap tahunnya adalah minimal 120\% dari modal minimum berbasis risiko. Jika perusahaan tidak bisa mencapai peraturan tersebut, menteri keuangan mampu bertindak kepada perusahaan yang tersebut.

Merupakan perusahaan asuransi jiwa tertua dan sangat dipercaya oleh masyarakat di Indonesia, PT Asuransi Jiwasraya dinasionalisasikan dan menjadi milik negara pada tahun 1960. Jiwasraya dimerger dengan 9 perusahaan asuransi milik Belanda pada tahun 1961. Nama perusahaan pun sempat berganti berkali-kali hingga akhirnya tahun 2003 ditetapkan dengan PT Asuransi Jiwasraya (Persero). Sebagai Badan Usaha Milik Negara yang bergerak dibidang asuransi dapat dikatakan PT Jiwasraya tidak memiliki pesaing yang cukup berarti. Namun seiring dengan berjalannya waktu pertumbuhan industri asuransi pun mulai berkembang pesat. Hal ini membuat pelaku-pelaku industri asuransi berlomba - lomba menawarkan produk baru yang sesuai dengan perkembangan kebutuhan masyarakat .

Namun bermula pada tahun 2002, PT Asuransi Jiwasraya dikabarkan sudah mengalami kesulitan. Ketika tahun 2016, PT Asuransi Jiwasraya telah diprediksi berisiko gagal membayar terhadap PT Hanson Internasional ketika transaksi investasi. Kemudian di tahun 2017 PT Asuransi Jiwasraya kembali mendapat opini tidak wajar didalam laporan keuangannya. Opini tersebut muncul bermula dari adanya kurang cadangan dana sebesar Rp 7,7 triliun. Pada tahun 2018-2019 diketahui Jiwasraya melakukan penyimpangan yang berindikasi fraud dalam mengolah saving plan dan investasi. PT Asuransi Jiwasraya diketahui memiliki 28 produk reksadana dan sebagian besar reksadana berkualitas rendah. Tidak disangka - sangka hal baru saja terungkap pada perusahaan asuransi tertua dan sangat dipercaya oleh masyarakat Indonesia, hal ini tentu saja menimbulkan kerugian bagi negara.

Melihat pada literatur empiris tentang topik tersebut, beberapa penelitian penting yang medukung yaitu, Handayani (2015) yang membuat penelitian dengan menganalisis kinerja keuangan perusahaan BUMN asuransi yang go public (menggunakan analisis ratio dan Risk Based Capital). Studi tersebut dilaksanakan melalui 9 perusahaan asuransi milik negara yang go public dengan jenjang waktu 3 tahun (20122014). Hasil penelitiannya menunjukan bahwa analisis rasio terbaik adalah adalah pada PT Asuransi Jiwasraya dan yang paling rendah adalah PT Asuransi Ekspor Indonesia dan Risk Based tertinggi terdapat pada PT Asuransi Jasa Raharja. Hal tersebut memperlihatkan bahwa perusahaan dengan nilai rasio sempurna tidak memiliki nilai Risk Based Capital yang tinggi.

Makalah yang disediakan oleh Sael dan Elly (2018), memiliki tujuan yaitu 
menganalisia laporan keuangan sebagai ukuran kesehatan bank dengan metode RGEC pada bank umum BUMN periode 2014-2016. Sampel dalam penelitian tersebut adalah 4 perusahaan perbankan yaitu BNI, BRI, BTN dan Mandiri. Hasil yang didapat membuktikan bahwa secara keseluruhan Bank Umum BUMN selama periode 2014-2016 mendapatkan penilaian yang sehat.

Melalui berbagai penelitian para peneliti terdahulu membuktikan bahwa analisis Rasio keuangan dan Risk Based Capital mampu menunjukan tingkat kesehatan dan posisi keuangan sebuah perusahaan. Kebanyakan penelitian sebelumnya menganalisa kesehatan keuangan pada perusahaan perbankan dan perusahaan asuransi pada umumnya. Pada hasil penelitian yang dilakukan Handayani (2015) membuktikan bahwa PT Asuransi Jiwasraya memiliki rasio terbaik dibandingkan PT Jasa Raharja dan PT Ekspor Indonesia. Hasil tersebut sangat berbanding terbalik dengan isu kebangkrutan yang menimpa PT Asuransi Jiwasraya baru - baru ini.

Dengan hal tersebut penelitian ini merupakan studi kasus pada perusahaan asuransi PT Asuransi Jiwasraya yang akhir -akhir ini sedang diterpa isu tidak sedap dan terancam kebangkrutan. Penelitian ini juga dilakukan guna mengkaji ulang sehingga mendapatkan jawaban yang tepat karena kebangkrutan yang menimpa PT Asuransi Jiwasraya tidak sesuai dengan fakta yang diungkapkan dalam penelitian (Handayani, 2015).

Temuan yang saling bertentangan serta hasil penelitian yang tidak sesuai dengan kenyataan telah membuat sulit bagi para pemain di sektor bisnis khususnya pada industri asuransi untuk mengatakan dengan pasti apakah mengetahui tingkat kesehatan sebuah perusahaan adalah usaha yang bermanfaat. Sehingga menimbulkan pertanyaan Bagaimana tingkat kinerja dan kesehatan PT Asuransi Jiwasraya menggunakan Rasio keuangan dan Risk Based Capital pada periode sebelum kebangkrutan.

Asuransi sendiri didefinisikan sebagai perjanjian antara dua pihak atau lebih, dimana pihak penanggung mengikat dirinya kepada tertanggung, dengan menerima premi asuransi (Firdaus dan Akmal, 2019).
Pada dasarnya asuransi memiliki tujuan yaitu semata - mata hanya untuk berjaga jaga jika terjadi sesuatu yang tidak sesuai dengan harapan (risiko). Hal ini tertulis pada Undang-Undang Republik Indonesia Nomor 2 Tahun 1992 tentang Usaha Asuransi Pasal 1. Menurut Suci (2019) bisnis asuransi adalah jenis bisnis yang diatur oleh pemerintah. Hal ini karena asuransi berkaitan dengan terkumpulnya dana dari masyarakat yang berupa premi asuransi. Hal ini membuat kinerja dan kesehatan keuangan perusahaan menjadi hal terpenting bagi pemangku kepentingan terutama masyarakat yang menggunakan asuransi.

Menurut Nurlatifah dan Mardian (2016) kinerja (performance) adalah gambaran tingkat pencapaian pelaksanaan suatu kegiatan dalam mewujudkan sasaran, tujuan, misi, dan visi organisasi yang tertuang dalam strategic planning suatu organisasi. Kinerja yang baik dan keuangan yang sehat dapat digunakan untuk membangun kepercayaan masyarakat. Untuk menilai kesehatan sebuah perusahaan dapat dilihat dari laporan keuangan. Maka dari itu hal ini menjadi tugas seorang manajer perusahaan memeberikan informasi - informasi bagi pemangku kepentingan dengan menerbitkan laporan keuangan.

Signaling Theory menjelaskan bagaimana sebuah perusahaan sebaiknya memberikan sinyal kepada pemangku kepentingan sebagai pengguna laporan keuangan. Sinyal ini dapat berupa iklan maupun informasi lainnya yang menggambarkan bahwa perushaan yang bersangkutan lebih baik dari perusahaan lainya. Sepanjang tahun perusahaan asuransi senantiasa mengevaluasi kegiatan operasional mereka baik identifikasi eksternal maupun internal yang dapat berpengaruh terhadap rasio solvabilitas mereka maupun rasio profitabilitas mereka. Pemerintah sebagai pembuat regulasi berkeinginan menjaga stabilitas kondisi berkembangnya industri perasuransian Indonesia melakukan penyesuaian secara merata yang berkenaan dengan kesehatan perusahaan asuransi dan perusahaan reasuransi. Dengan menetapkan Peraturan Menteri Keuangan Nomor 53/ PMK.OIO/ 2012 tentang kesehatan keuangan 
perusahaan asuransi dan perusahaan reasuransi yang menilai kesehatan keuangan perusahaan dengan Risk Based Capital. Menurut Sujana dan Kadek (2017), Risk Based Capital adalah batasan tingkat solvabilitas minimal yang wajib digapai oleh sebuah perusahaan asuransi dan reasuransi.

Risk Based Capital dapat digunakan sebagai petunjuk atau digunakan sebagai karakteristik bahwa perusahaan yang bersangkutan dalam keadaan sehat dan terjamin atau tidak. Seringkali nilai Risk Based Capital yang telah memenuhi standar dapat dijadikan sebagai media promosi agar masyarakat tertarik untuk membeli polis perushaan yang bersangkutan (Nurfadila, 2015). Risiko terbesar perusahaan asuransi adalah tidak bisa membayar kewajiban jangka pendek maupun jangka panjang. Hal ini dapat berakibat pada kebangkrutan seperti yang dialami PT Asuransi Jiwasraya baru - baru ini. Kebangkrutan sendiri dapat berasal dari faktor eksternal maupun internal. Tentunya apabila perusahaan mengalami kebangkrutan banyak pihak yang akan dirugikan beberapa diantaranya adalah investor dan kreditur (Syafitri dan Wijaya, 2014). Oleh sebab itu Risk Based Capital juga diperlukan sebagai alat atau metode yang digunakan untuk memprediksi ada tidaknya potensi kebangkrutan pada sebuah perusahaan.

Gejala awal dari kebangkrutan yaitu terjadinya Financial Distress. Penelitian yang dilakukan Nilmawati (2011) menemukan bahwa rasio keuangan mampu memprediksi kondisi financial distress sebuah perusahaan. Financial Distress dimulai dari terjadinya ketidakpastian pada profitabilitas perusahaan di masa yang akan datang. Jika hutang sebuah perusahaan lebih besar dari aktiva atau harta yang dimiliki oleh perusahaan, sehingga perusahaan tidak mampu memenuhi kewajiban pada kreditur pada saat jatuh tempo perusahaan akan dinyatakan gagal atau bangkrut (Cheluget et al., 2013).

Maka dari itu Penelitian ini memiliki tujuan, yaitu untuk mengukur tingkat kinerja dan kesehatan keuangan perusahaan asuransi PT Asuransi Jiwasraya melalui Risk Based Capital dan Rasio keuangan ditengah maraknya kasus yang dihadapi. Penting bagi pemangku kepentingan untuk mengetahui posisi keuangan dan tingkat kesehatan PT Asuransi Jiwasraya. Hal ini juga dapat digunakan untuk membandingkan satu pos dengan pos laporan keuangan lainnya.

Studi ini akan memiliki arti penting bagi sejumlah pemangku kepentingan. Studi ini akan bermanfaat bagi investor dan perusahaan - perusahaan di Bursa Efek Indonesia agar memiliki pemahaman tentang pentingnya mengukur kinerja dan kesehatan keuangan suatu perusahaan untuk memprediksi yang akan terjadi hari ini maupun yang akan datang dan mengambil keputusan - keputusan keuangan. Itu juga akan bermanfaat bagi perusahaan lain dalam industri kompetitif dan lainnya yang tidak terdaftar di Bursa Efek Indonesia. Studi ini akan memberikan wawasan lebih dalam hubungan antara Risk Based Capital dengan kesehatan keuangan sebuah perusahaan. Studi ini juga akan berkontribusi pada sebagian besar pengetahuan dan penelitian di Universitas karena akan digunakan sebagai dasar referensi oleh siswa untuk studi selanjutnya di bidang analisis kesehatan keuangan sebuah perusahaan.

\section{METODOLOGI}

\section{a. Jenis Penelitian}

Dalam studi tentang hal ini digunakan jenis penelitian deskriptif dengan menggunakan pendekatan kuantitatif. Pendekatan kuantitatif merupakan sebuah metode penelitian yang digunakan untuk menemukan hasil penelitian dengan data yang berupa angka sebagai alat untuk mengukur apa yang ingin diketahui (Ratna, 2019). Sedangkan Penelitian deskriptif merupakan jenis penelitian yang memaparkan suatu keadaan atau fenomena tertentu, tidak memilah - milih faktor atau varabel tertentu (Nurfadila, 2015).

\section{b. Sumber dan Teknik Pengumpulan Data}

Sumber data dalam penelitian ini yaitu merupakan data sekunder didapat dari laporan keuangan perusahaan asuransi PT Jiwasraya. Teknik pengumpulan data yang dilakukan adalah dengan mengambil dari laporan keuangan PT Asuransi Jiwasraya periode tahun 2008 - 2017 atau masa masa sebelum terjadinya kabangkrutan. 
c. Teknik Analisa Data

1. Mengukur dan menyimpulkan Risk Based Capital sesuai dengan peraturan yang dibuat oleh pemerintah pada PT Asuransi Jiwasraya kemudian dari tahun ke tahun akan dibandingkan pada tahun 2008 hingga 2017.

$$
R B C=\frac{\text { TS (Tingkat Solvabilitas) }}{\text { Batas TS Minimum }}
$$

2. Mengukur dan menyimpulkan perhitungan rasio-rasio keuangan pada PT Asuransi Jiwasraya kemudian dibandingkan dari tahun 2008 hingga 2017. Rasio keuangan yang dihitung terdiri dari :

- Rasio Profitabilitas : untuk mengukur Rasio Pengembalian Investasi (RPI) dapat digunakan cara sebagai berikut : $R P I=\frac{\text { Pendapatan Bersih Investasi }}{\text { Rata }- \text { rata Investasi }}$

- Rasio Likuiditas : menghitung Rasio Likuiditas ( $R L)$ kekayaan dapat diukur dengan cara :

$$
R L=\frac{\text { Kewajiban }}{\text { Aktiva yang diperkenankan }}
$$

- Rasio Stabilitas Premi : Untuk menghitung Rasio Retensi Diri (RRD) yaitu dengan cara :

$$
R R D=\frac{\text { Premi Netto }}{\text { Premi Bruto }}
$$

\section{HASIL PEMBAHASAN}

Analisis Risk Based Capital

Risk Based Capital didefinisikan sebagai sekumpulan ekuitas yang digunakan untuk meminimalisir risiko - risiko yang akan saja terjadi. Untuk sebuah perusahaan asuransi, Risk Based Capital diyakini sebagai keseluruhan ekuitas yang diperlukan untuk memberi keyakinan stakeholder yang berhubungan misalnya masyarakat dan kreditur dalam peluang insolvent atau modal negatif. Adanya Risk Based capital diupayakan mampu sebagai cermin dari kekuatan perusahaan dalam membiayai klaim-klaim yang mungkin sudah jatuh tempo. Menganalisis Risk Based Capital dimanfaatkan untuk mengukur nilai solvabilitas perusahaan dalam mempertanggung jawabkan risiko kerugian yang akan saja terjadi akibat deviasi diantara pengelolaan kekayaan dan kewajiban. Untuk menganalisis Risk Based Capital PT. Asuransi Jiwasraya digunakan data yang bersumber dari laporan tingkat solvabilitas dan Batas Tingkat Solvabilitas Minimum (BTSM) atau disebut Modal Minimum Berbasis Risiko (MMBR). Setiap perusahaan asuransi atau perusahaan reasuransi diharuskan mempunyai Risk Based Capital paling minim 120\%. Kewajiban tersebut telah diatur oleh pemerintah dalam Peraturan Menteri Kcuangan Nomor 53/ PMK.OIO/ 2012. Tingkat Solvabilitas adalah selisih antara aktiva dengan jumlah kewajiban. Sedangkan Batas Tingkat Solvabilitas Minimum atau Modal Minimum Berbasis Risiko berbedabeda tergantung yang ditentukan perusahaan. Nilai Risk Based Capital yang telah dihitung dapat diganti ke dalam hasil presentase (Gambar 1).

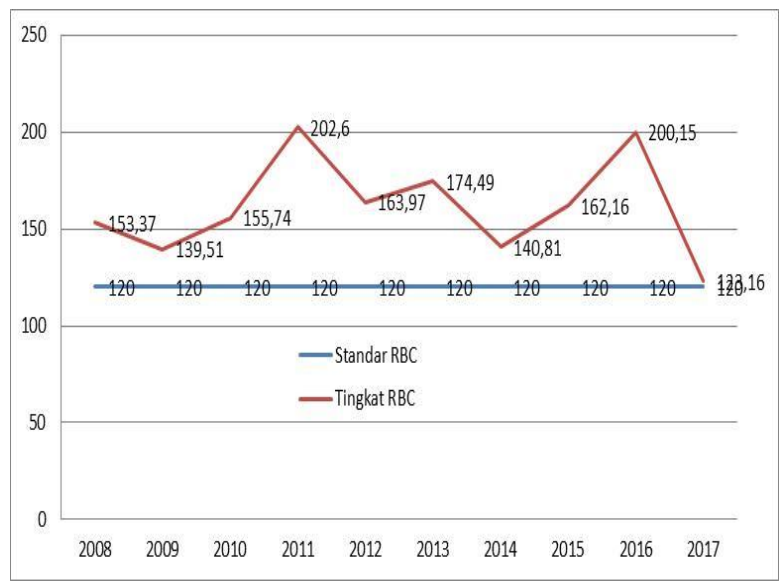

Gambar 1. Hasil Analisa Risk Based Capital PT. Asuransi Jiwasraya 2008-2017

Sesuai dengan Gambar 1 diketahui hasil Risk Based Capital PT. Asuransi Jiwasraya pada tahun 2008-2017sudah melampaui batas normal yang diatur oleh pemerintah yaitu paling sedikit $120 \%$. Hasil tersebut memilikiarti bahwa PT Asuransi Jiwasraya memiliki kekuatan yang baik dalam memenuhi risiko yang mungkin akan terjadi akibat deviasi dalam pengelolaan kekayaan dan kewajiban. Berdasar perhitungan Risk Based Capital perusahaan tertinggi terlihat pada tahun 2011 sejumlah $202,60 \%$ yang berarti perusahaan memiliki harta $202,60 \%$ lebih banyak dari hutangnya termasuk untuk membayar setiap risiko yang dihadapi yang dipertanggung jawabkan perusahaan asuransi terkait. 
Kesehatan keuangan PT. Asuransi Jiwasraya pada tahun 2007 hingga 2010 sesuai Risk Based Capital menggambarkan dalam kondisi kurang baik, karena hasilnya tidak jauh dari batas minimal. Sedangkan pada tahun 2011 Risk Based Capital mulai meningkat sebesar 46,86\% artinya kesehatan perusahaan mulai membaik. Hingga tahun 2016 Risk Based Capital PT Asuransi Jiwasraya naik dan turun nilainya dalam jumlah yang tidak teratur atau sering disebut mengalami fluktuasi. Pada tahun 2017 nilai Risk Based Capital PT Asuransi Jiwasraya menurun drastis pada angka $123,16 \%$ hal ini menandakan kondisi kesehatan perusahaan kurang baik artinya PT Asuransi Jiwasraya tersebut minimal memiliki kekayaan $23,16 \%$ lebih tinggi dari nilai hutang perusahaan sudah termasuk untuk membiayai setiap risiko pertanggungan yang dimiliki oleh PT Asuransi Jiwasraya. Namun secara umum nilai Risk Based Capital PT Asuransi Jiwasraya cenderung menurun mendekati batas minimal rasio solvabilitas yang di tetapkan oleh Peraturan Menteri Keuangan. Artinya kesehatan PT Asuransi Jiwasraya secara keseluruhan cenderung kurang baik bahkan memburuk.

\section{Penilaian Kinerja Keuangan PT. Asuransi Jiwasraya}

Dengan menilai kinerja keuangan peneliti mampu menggambarkan posisi keuangan sebuah perusahaan tentang kelebihan serta kekurangannya. Analisis rasio keuangan pada PT Asuransi Jiwasraya digunakan data yang tertulis di laporan keuangan yang terdiri dari neraca dan laporan laba rugi.Analisis rasio yang dilaksanakan diukur memakai metode perbandingan time series analysis yaitu dengan membandingkan rasio keuangan perusahaan mulai tahun hingga tahun. Dalam studi ini analisis rasio keuangan diukur untuk periode 2008 hingga 2017. Hasil pengukuran rasio keuangan perusahaan yaitu seperti dibawah :

\section{a. Rasio Likuiditas}

Rasio Likuiditas Aset berguna untuk menghitung kekuatan perusahaan dalam membayar kewajibannya dengan aset yang dimiliki. Rasio likuiditas mempunyai batas normal 120\%. Hasil pengukuran rasiolikuiditas disesuaikan ke dalam sebuah presen, dijabarkan pada Tabel 1 :

Tabel 1. Rasio Likuiditas PT Asuransi Jiwasraya 2007-2018

\begin{tabular}{cc}
\hline Tahun & Rasio Likuiditas (\%) \\
\hline 2008 & 293,18 \\
2009 & 512,85 \\
2010 & 385,15 \\
2011 & 356,54 \\
2012 & 272,32 \\
2013 & 237,75 \\
2014 & 566,66 \\
2015 & 374,78 \\
2016 & 164,03 \\
2017 & 147,50 \\
\hline
\end{tabular}

Sesuai pada Tabel 1 dituliskan bahwa rasio likuiditas aset pada PT Asuransi Jiwasraya kurang baik karena melebihi batas normal maksimal yaitu $120 \%$. Tetapi kelebihan rasio ini secara umum cenderung menurun setiap tahunnya hanya pada tahun 2009 dan 2014 yang mengalami kenaikan. Perhitungan dalam Tabel 1 menunjukan bahwa perusahaan dalam keadaan kurang mampu memenuhi kewajiban yang dimiliki dengan aset/kekayaan yang dimiliki.

\section{b. Rasio Profitabilitas}

Peneliti menggunakan rasio pengembalian investasi berguna untuk menghitung berapa besar hasil yang dicapai dari kegiatan investasi yang dilaksanakan. Rasio pengembalian investasi mempunyai standar normal paling sedikit 15\% (Tabel 2).

Tabel 2. Rasio Pengembalian Investasi PT Asuransi Jiwasraya 2008-2017

\begin{tabular}{cc} 
Tahun & Rasio Profitabilitas \\
\hline 2008 & 10,08 \\
2009 & 11,31 \\
2010 & 11,25 \\
2011 & 12,1 \\
2012 & 13,97 \\
2013 & 15,56 \\
2014 & 9,99 \\
2015 & 4,72 \\
2016 & 11,29 \\
2017 & 15,65 \\
\hline
\end{tabular}

Hasil rasio pengembalian investasi PT Asuransi Jiwasraya memperlihatkan masih 
cenderung rendah setiap tahun masih dibawah batas normal yaitu $15 \%$ hanya pada tahun 2017 dan 2013 saja yang melebihi batas normal minimal. Namun rasio pengembalian investasi dari tahun 2010 hingga 2013 dan 2015 hingga 2017 mengalami peningkatan hinggs $15,65 \%$. Hal ini menunujukan pendapatan bersih perusahaan atas investasi yang dilakukan mulai meningkat atau membaik dibandingkan rata- rata investasi yang dilaksanakan.

\section{c. Rasio Stabilitas Premi}

Untuk mengukur stabilitas premi peneliti menggunakan rasio retensi diri. Rasio retensi digunakan untuk menggambarkan tingkat retensi perusahaan dalam bertanggung jawab atas risiko yang dimiliki. Tidak memiliki standar normal untuk rasio retensi diri, namun semakin besar hasil yang diperoleh akan lebih baik. Hasil rasio tersebut dalam berupa persen dapat dilihat pada Tabel 3 sebagai berikut :

Tabel 3. Rasio Retensi Diri PT Asuransi Jiwasraya Periode 2008 - 2017

\begin{tabular}{cc}
\hline Tahun & Rasio Stabilitas Premi \\
\hline 2008 & 527,36 \\
2009 & 309,43 \\
2010 & 348,42 \\
2011 & 332,46 \\
2012 & 340,07 \\
2013 & - \\
2014 & - \\
2015 & - \\
2016 & - \\
2017 & - \\
\hline
\end{tabular}

Rasio retensi PT Asuransi Jiwasraya terlihat membaik walaupun tidak stabil. Namun pada tahun - tahun akhir dari 2011 hingga 2012 rasio retensi perusahaan cenderung meningkat. Pada tahun 2013 hingga 2017 hasil rasio retensi diri tidak dapat diketahui karena tidak terdapat perhitungannya. Hasil paling baik terlihat pada tahun 2008 dengan rasio retensi diri yaitu sebesar $527,36 \%$ yang memiliki arti $527,36 \%$ dari premi bruto adalah premi netto. Hal tersebut memiliki arti nilai premi yang dapat ditahan sendiri bandingkan dengan premi yang diterima secara langsung adalah sebesar $527,36 \%$.

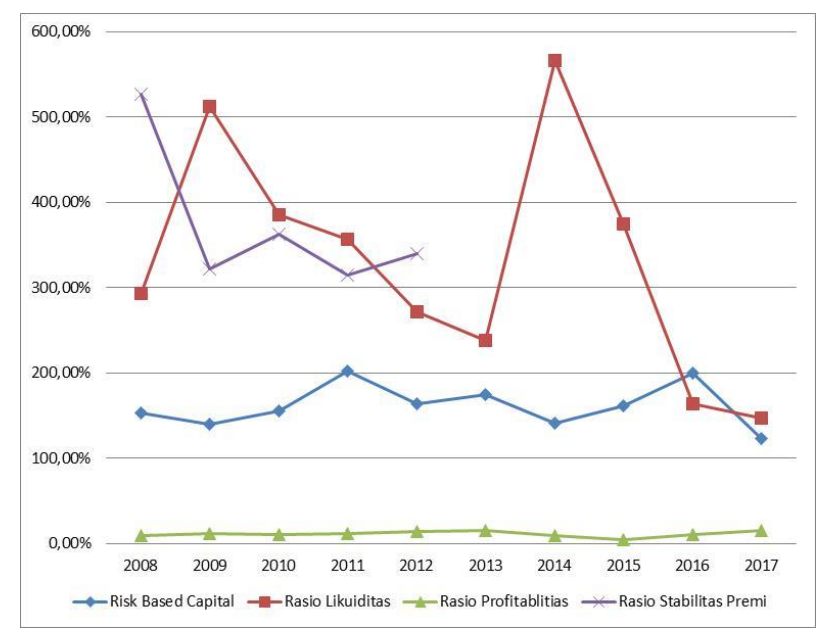

Gambar 2. Hasil Analisis Rasio Keuangan dan Risk Based Capital PT Asuransi Jiwasraya periode 2008 - 2017

Gambar 2 menunjukan pergerakan rasio keuangan dan nilai Risk Based Capital dari waktu ke waktu. Namun terdapat pola pergerakan yang sama antara periode 2009 hingga 2011 dan periode 2012 hingga 2014 pada rasio profitabilitas dan nilai Risk Based Capital. Hal yang menjadi kendala adalah pada tahun 2014 terjadi likuiditas naik atau dengan kata lain perusahaan tidak mampu membayar kewajiban dengan aset yang dimiliki, hal itu terjadi akibat dari menurunnya angka profitabilitas sehingga nilai Risk Based Capital juga menurun. Kendala yang selanjutnya juga pada rasio likuiditas yang naiik pada tahun 2009 yang diakibatkan oleh menurunnya stabilitas premi pada tahun tersebut. Risk Based Capital pada tahun tersebut juga seirama menurun.

\section{KESIMPULAN}

Dapat disimpulkan dalam penelitian ini sesuai dengan penilaian rasio keuangan dan Risk Based Capital kinerja dan kesehatan PT Asuransi Jiwasraya relatif stabil namun terjadi penyimpangan yang alami pada tahun tertentu. Kesehatan keuangan berdasar Risk Based Capital PT. Asuransi Jiwasraya dalam keadaan baik. Terlihat dari hasil rasio keuangan dan tingkat Risk Based Capital bahwa perusahaan yang dikatakan sehat belum tentu memiliki kelola keuangan yang baik. Kesimpulan secara rinci sebagai berikut: 
1. Rasio Likuiditas

Rasio Likuiditas Aset berguna untuk menghitung kekuatan perusahaan dalam membayar kewajibannya menggunakan aset yang dimiliki. Hasil rasio likuiditas aset Jiwasraya menggambarkan bahwa PT Asuransi Jiwasraya kurang mampu dalam membayar kewajibannya dengan aset yang perusahaan miliki.

2. Rasio Profitabilitas

Peneliti menggunakan rasio pengembalian investasi bermanfaat untuk menghitung berapa besar hasil yang didapat berdasar investasi yang dilaksanakan. Rasio profitabilitas yang diukur dengan rasio pengembalian investasi terlihat relatif stabil namun rata -rata disetiap tahunnya rasio pengembalian investasi belum mencapai pada batas normal. Hanya pada tahun 2013 dan 2017 saja yang mampu memenuhi batas normal.

3. Rasio Stabilitas Premi

Rasio stabilitas premi yang ditunjukan rasio retensi diri sudah mulai membaik. Rasio retensi diri digunakan untuk menggambarkan angka retensi perusahaan yang dugunakan untuk bertanggung jawab atas risiko yang dimiliki. Hal ini ditunjukkan dengan peningkatan rasio pada tahun 2009 dengan 2010 dan 2011 hingga tahun 2012 yang menggambarkan bahwa retensi perusahaan semakin baik.

4. Risk Based Capital

Risk Based Capital perusahaan memperlihatkan hasil yang baik. Hal ini tergambarkan pada hasil pencapaian setiap tahunnya yang mampu melampaui standar walaupun tidak jauh dari nilai standar yang ditetapkan pemerintah. Ini memiliki arti PT Asuransi Jiwasraya selama ini dapat bertanggung jawab atas risiko kerugian yang ada akibat terjadinya deviasi dalam mengeola kekayaan dan kewajiban.

Sesuai hasil analisis kinerja dan kesehatan keuangan PT. Asuransi Jiwasraya maka peneliti dapat memberikan rekomendasi sebagai berikut:

1. Saran bagi perusahaan Agar perusahaan mampu meningkatkan kemampuan dalam menganalisis kembali ketika menempatkan investasi. Perusahaan direkomendasikan untuk memilih investasi dengan pajak yang tidak terlalu besar atau memilih dividen dan bunga yang lebih besar. Perusahaan juga harus mempertimbangkan untuk menaikkan sebaran dan nilai investasi portofolionya.Perusahaan juga perlu memperhatikan koran keuangan sebagai alat - alat prediksi kebangkrutan sehingga mampu mengambil keputusan keuangan dimasa mendatang.

2. Saran untuk peneliti selanjutnya Bagi peneliti selanjutnya, jika akan menganalisis kasus yang sama seperti dalam penelitian ini akan lebih baik jika penelitian yang dibuatmenggunakan rasio - rasio keuangan perusahaan asuransi yang lebih lengkaphal itu dapat mempermudah pemangku kepentingan atau perusahaan terkait untuk melihat kinerja keuangan perusahaan tersebut. Tidak hanya itu bagi peneliti selanjutnya mungkin mampu menambahkan rasio keuangan yang terdapat didalam teori Early Warning System yang lebih lengkap sehingga akan lebih sempurna.

\section{DAFTAR PUSTAKA}

Cheluget, J., Gekara, M., Ngugi, P., \& Keraro, V. 2013. Efficiency As A Determinant Of Financial Distress In Insurance Companies In Kenya. Prime Journal Of Business Administration And Management (Bam).

Firdaus, R., \& Akmal, N. 2019. Asuransi Jiwa Dalam Meningkatkan Pelayanan Kepada Nasabah (Studi Kasus Pada Pt Asuransi Jiwasraya Persero Area Lhokseumawe ).

Handayani, K. 2015. Analisis Kinerja Keuangan Perusahaan Bumn Asuransi yang Go Publik (Menggunakan Analisis Ratio dan Risk Based Capital ). 2(2), 188-201.

Janudin. 2018. Analisis Rasio Keuangan Untuk Mengukur Kinerja Keuangan (Pada Perusahaan Transportasi Udara Kawasan Asia). 1(3), 106-124. 
Maharani, F. 2019. Analisis Pengaruh Rasio Keuangan Terhadap Perubahan Laba Pada Perusahaan Manufaktur Sektor Industri Barang Konsumsi Yang Terdaftar di Bursa Efek Indonesia Tahun 2007-2011. Fakultas Ekonomi dan Bisnis. Universitas Muhammadiyah.

Nilmawati. 2011. Rasio - Rasio Keuangan dan Penggunaannya Dalam Memprediksi Kondisi Financial Distress Perusahaan.

Nurfadila, S. 2015. Analisis Rasio Keuangan Dan Risk Based Capital Untuk Menilai Kinerja Keuangan Perusahaan Asuransi (Studi Pada PT.Asei Reasuransi Indonesia (Persero) Periode 2011-2013). 22 (1), 1-9.

Nurlatifah, A. F., \& Mardian, S. 2016. Kinerja Keuangan Perusahaan Asuransi Syariah Di Indonesia: Surplus On Contribution. Akuntabilitas: Jurnal IImu Akuntansi, 9 (April), 73-96.
Https://Doi.Org/10.15408/Akt.V9i1.3590

Ratna, E. 2019. Analisis Pengaruh Rasio Early Warning System Terhadap Risk Based Capital Perusahaan Asuransi Jiwa Syariah di Indonesia.

Sael, A., \& Elly, J. T. 2018. Analisis Laporan Keuangan Sebagai Ukuran Kesehatan Bank Dengan Metode RGEC Pada Bank Umum Bumn Periode 2014-2016 Analysis Of Financial Statements As A Bank Health Size Using Rgec Methods.6(4), 3943-3952.

Sujana, E., \& Kadek, N. (2017). Pengaruh Pendapatan Premi, Hasil Underwriting, Hasil Investasi Dan Risk Based Capital Terhadap Laba Perusahaan Asuransi. 7.

Syafitri \& Wijaya. (2014). Analisis Komparatif Dalam Memprediksi Kebangkrutan Pada Pt . Indofood Sukses. 1-14. 
2 Jurnal Pamator 